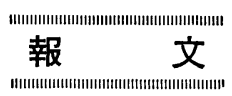

\title{
ピラゾレート*の主剤粒度の除草効果に及ぼす影響**
}

\author{
谷 沢 欽 次, 藤本昌彦, 川久保克彦 \\ 河西史人，本間豊邦，中村利家*** \\ 三共株式会社農薬研究所
}

（昭和 62 年 3 月 12 日受理）

\section{Influence of the Particle Size on the Herbicidal Efficacy of Pyrazolate****}

\author{
Kinji Tanizawa, Masahiko Fujımoto, Katsuhiko Kawakubo, \\ Fumito Kasai, Toyokuni Honma and Toshiie Nakamura*** \\ Agricultural Chemicals Research Laboratories, Sankyo Co., Ltd., \\ Yasu-cho, Yasu-gun, Shiga 520-23, Japan
}

\begin{abstract}
Relationship between the particle size and the herbicidal activity of pyrazolate was investigated under paddy field conditions. Suspensions containing pyrazolate particles classified into different sizes were tested in a greenhouse. By pre-emergence application, fractions less than $44 \mu \mathrm{m}$ in diameter were effective against Sagittaria pygmaea at a dose of $0.5 \mathrm{~kg} / \mathrm{ha}$, while particles larger than $20 \mu \mathrm{m}$ were not active enough against Echinochloa oryzicola at the same dose. Pyrazolate larger than $10 \mu \mathrm{m}$ in diameter gave unsatisfactory efficacy against Cyperus serotinus even at a dose of $1 \mathrm{~kg} / \mathrm{ha}$. As pyrazolate got coarse, the activity decreased more remarkably by post-emergence application. Granules containing $10 \%$ pyrazolate were prepared by an extrusion method with the active ingredient pulverized into 1.36, 1.76, 2.03, $2.15,5.13$, or $7.47 \mathrm{~m}^{2} / \mathrm{g}$ of a specific surface area $\left(S_{w}\right)$ and applied into pots and paddy fields. In the pot tests, granules containing the coarsest pyrazolate were less effective than others. In the field, granules containing pyrazolate of 2.03 or $2.15 \mathrm{~m}^{2} / \mathrm{g}$ of $S_{w}$ were more effective than those containing either coarser or finer pyrazolate. The results indicate that the herbicidal efficacy of pyrazolate is affected by its particle size, and that pyrazolate should be pulverized into $c a .2 \mathrm{~m}^{2} / \mathrm{g}$ of $S_{w}$ in order to demonstrate sufficient activity in paddy fields in granule form.
\end{abstract}

\section{緒言}

ピラゾレート1) [4-(2,4-dichlorobenzoyl)-1,3-dimethyl5 -pyrazolyl $p$-toluenesulfonate, pyrazolate] は 1973 年に

* 4-(2,4-Dichlorobenzoyl)-1,3-dimethyl-5-pyrazolyl $p$-toluenesulfonate

** ピラゾレート製剤に関する研究（第 2 報）(第 1 報： 文献 34）参照） Studies on Pyrazolate Formulation (Part 2). For Part 1, see Ref. 34).

*** 現在: 島根大学農学部

Present address: Department of Environmental Sciences, Shimane University, Nishikawatsucho, Matsue 690, Japan
三共 (株) において見いだされた水田用除草郕で，稲に 対する安全性がきわめて高く，1 年生雑草はもとより多 年生雑草, とくに, 従来防除の難しいとされていたウリ カワに対して優れた除草活性を有し,わが国で 1980 年に サンバード粒剤として実用に供され, その後数種の混合 用が開発されている。

ピラゾレートは, 4-(2,4-dichlorobenzoyl)-1,3-dimethyl5-hydroxypyrazole(DTP)1) のパラトルエンスルホン酸エ ステルである. DTP はそれ自体，水田の 1 年生および 多年生雑草に対し, 強い除草活性を有するが, 解離性の 水酸基を有し, 水溶解度が高く $\left(\mathrm{pH} 5.9,4500 \mathrm{ppm} / 25^{\circ} \mathrm{C}\right)$, ときに稲幼苗に薬害を起こすことがあるうえに, 流亡・ 溶脱・光分解 ${ }^{29)}$ ・微生物分解 ${ }^{30)}$ ・土堙吸着 ${ }^{31)}$ により短 
期間のうちにその活性を失うため，残効性が短いという 欠点があった。一方，ピラゾレートは水にきわめて難溶 性の結晶性固体 (蒸留水中溶解度 $0.056 \mathrm{ppm} / 25^{\circ} \mathrm{C}$ ) であ るが, 水に溶けたものは比較的容易に加水分解され $(\mathrm{pH}$ 7.0 で半減期が $25 \mathrm{hr})^{32}$ ), 活性本体の DTP となって除 草効果を発現すると考えられている.

水に溶けにくい固体化合物の粒度と効力の関係につい ては多くの報告 ${ }^{223)}$ がある。一般に, 主剂を微粉砕する と生物活性は高まるが，主凨によっては残効性が短くな ったり，作物に対する薬害を助長したりすることがあり， 最適粒度があることも多い。除草㘊でも，近内 ${ }^{22}$ は (2,6-dichlorobenzonitrile) で主剂粒度が粗いと効力が低 いことを認め, アトラジン (2-chloro-2', 6'-diethyl- $N$ methoxymethylacetanilide) も温室内発芽後処理で粒度が 細かいほうが効力が高いとの報告がある23)。また，トリ アジンや尿素系除草郕も, 効力を高めるうえで主郕の微 粉砕が必要とされている10). 本報ではピラン゙レートの精 度と除草効果の関係について報告する。

\section{実 験 方 法}

\section{1. 供試製剤の調製方法}

1）ピラゾレートの分級懸濁液

ピラゾレートの工業用原体（純度 98\%）をらい解機で 粉砕し, 分散媒にポリオキシェチレンノニルフェニルェ ーテル〔ニューニール566®，日本乳化剂（株）〕の 0.1 $\mathrm{w} / \mathrm{v} \%$ 水溶液を用いて分散させ，以下の方法で分級懸濁 液を得た。

粒子径 $0 \sim 5 \mu \mathrm{m}(\mathrm{A}), 5 \sim 10 \mu \mathrm{m}(\mathrm{B}), 10 \sim 20 \mu \mathrm{m}(\mathrm{C})$ の 各画分は自然沈降による分級を繰り返し，また20 37 $\mu \mathrm{m}(\mathrm{D}), 37 \sim 44 \mu \mathrm{m}(\mathrm{E})$ の各画分は目開き $20,37,44 \mu \mathrm{m}$ の標準ふるいを用いて湿式ふるい分け法により分級し た. 各画分はピラゾレートを $25 \mathrm{w} / \mathrm{w} \%$ の濃度で含有す る懸罍液とした。

2）粒度の異なるピラゾレート粉砕品とその粒剤

(1) ピラゾレート粉砕品

ジェット粉碎機，および攪找型粉砕機を用い, Table 1 の処方でピラン゙レートを粉砕し，それぞれ主剤粒度の異 なる粉砕品を得た。

サンプル I， II， III Table 1 の乾式プレミックスを ジェット粉研機〔ジェットミル@PJM100NP型, 日本二 ニーマチック(株)」により供給速度 $3 \mathrm{~kg} / \mathrm{hr}$, 空気圧 6.5 $\mathrm{kg} / \mathrm{cm}^{2}$ で 3 回繰り返し粉砕し, 各 $1,2,3$ 回粉砕した 段階で採取した粉砕品, サンプルIVはジェット粉砕機 〔ジェットオーマイザー® 0608 型, セイシン企業(株)]に より供給速度 $400 \mathrm{~kg} / \mathrm{hr}$, 空気圧 $7 \mathrm{~kg} / \mathrm{cm}^{2}$ で 4 回繰り返
Table 1 Recipes of pyrazolate premix for pulverizing.

\begin{tabular}{|c|c|c|c|}
\hline \multicolumn{2}{|c|}{ Dry pulverizing } & \multicolumn{2}{|c|}{ Wet pulverizing } \\
\hline & $\% \mathrm{w} / \mathrm{w}$ & & $\% \mathrm{w} / \mathrm{w}$ \\
\hline $\begin{array}{c}\text { Pyrazolate } \\
\text { tech. }{ }^{\text {a }}\end{array}$ & 50.00 & $\begin{array}{c}\text { Pyrazolate } \\
\text { tech. }{ }^{a)}\end{array}$ & 63.00 \\
\hline $\mathrm{CaCO}_{3}{ }^{\mathrm{b})}$ & 37.50 & $\begin{array}{l}\text { Neocol } \\
\quad \text { SWCE }\left({ }^{0}\right)\end{array}$ & 0.85 \\
\hline Silica sand ${ }^{c}$ ) & 11.50 & Water & 36.15 \\
\hline $\mathrm{PAP}^{\mathrm{d})}$ & 1.00 & & \\
\hline
\end{tabular}

a) Purity $98 \%$.

b) Heavy calcium carbonate.

c) $0.297-0.105 \mathrm{~mm} \phi$.

d) Mixture of mono-, di- and tri-iso-propyl ester of phosphoric acid (Nihon Kagaku Co., Ltd.).

e) An anionic surfactant (Dai-ichi Kogyo Seiyaku Co., Ltd.).

Table 2 Recipes of $10 \%$ granules of pyrazolate.

\begin{tabular}{|c|c|c|c|}
\hline \multicolumn{2}{|c|}{ Dry-pulverized premix } & \multicolumn{2}{|c|}{ Wet-pulverized premix } \\
\hline & $\% \mathrm{w} / \mathrm{w}$ & & $\% \mathrm{w} / \mathrm{w}$ \\
\hline $\begin{array}{c}\text { Pyrazolate } \\
\text { premix }^{\text {a) }}\end{array}$ & 21.4 & $\begin{array}{r}\text { Pyrazolate } \\
\text { premix }^{\text {a }}\end{array}$ & 16.7 \\
\hline Talc & 54.6 & Talc & 65.3 \\
\hline Bentonite $^{\mathrm{b}}$ ) & 22.0 & Bentonite $^{\mathrm{b}}$ ) & 22.0 \\
\hline Amicol No.5@() & 1.5 & Amicol No.5®c) & 1.5 \\
\hline Disrol H-12@d) & 2.0 & Disrol H-12®d) & 2.0 \\
\hline
\end{tabular}

a) See Table 1 .

b) Sodium bentonite.

c) Dextrin (Nichiden Kagaku Co., Ltd.).

d) An anionic surfactant $(25 \%$ aq. solution, Nihon Nyukazai Co., Ltd.).

し粉砕した粉砕品である. また，サンプルVおよびVは, Table 1 の湿式プレミックス $2.3 \mathrm{~kg}$ 学藽拌型粉砕機〔ア トライター® MA1S 型，(株)三井三池製作所]により， 直径 $4 \mathrm{~mm}$ のステンレススチールボール $18.8 \mathrm{~kg}$, 攪拌 回転数 $180 \mathrm{rpm}$ で各 $1 ， 2$ 時間粉砕した懸濁剤である.

(2) ピラゾレート粒剂

上記粉砕品を用い, Table 2 の処方でピラゾレート 10 $\%$ 粒剂を調製した。粒剂は押し出し造粒機〔エックペレ ッター® EXK-1型, 不二パウダル(株), スクリーン径 0.7 $\mathrm{mm}$ ] で造粒し, $70^{\circ} \mathrm{C}$ の送風乾燥機中で乾燥後, 開孔径 $1.000 \mathrm{~mm}$ のふるい上から押し出し, 開孔径 $0.297 \mathrm{~mm}$ の ふるいで微細部分を除去した. 粒剤のサンプルナンバー には対応する粉砕品のナンバーの後にGを付した。 


\section{2. 粒度測定法}

1）ピラゾレート分級品の粒度

光透過式粒度分布測定機 [SK 型，セイシン企業(株)] を用いて測定した。吸光係数の補正 ${ }^{24)}$ は行なわず, 結果

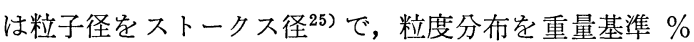
で示した.

2）ピラゾレート粉砕品の粒度

アルキルベンゼンスルホン酸のナトリウム塩を主成分 とする界面活性剂〔ネオペレックスパウダーNo. $1 巴$, 花王アトラス(株)] の $0.2 \mathrm{w} / \mathrm{v} \%$ 水溶液を分散媒とし, アンドレアーゼンピペット ${ }^{26)}$ で測定した. $5,10,20 \mu \mathrm{m}$ 部分の測定は沈降距離を $20 \mathrm{~cm}$ とし, 乾式粉砕品はピペ ット中に $3 \mathrm{~g}$ を, 湿式粉砕品は $1.4 \mathrm{~g}$ を分散させた. 1.2 および $2.5 \mu \mathrm{m}$ 部分の測定は，測定時間を短縮するため 沈降距離を $10 \mathrm{~cm}$ とし, 乾式粉砕品は $3 \mathrm{~g}$ を, 湿式粉砕 品は $0.95 \mathrm{~g}$ を分散させた. 試料の分散には家庭用ミキサ 一を用いた。測定は対流の影響を防ぐため $20^{\circ} \mathrm{C}$ 恒温室 に置いた水槽中で行なった. サンプリング時間は，分散 媒の密度および粘度に $20^{\circ} \mathrm{C}$ の水の值 ${ }^{27)}$ を用い, ピラゾ レートの密度は $1.4683 \mathrm{~g} / \mathrm{cm}^{3}$ としてストークス式 ${ }^{25)}$ り求めた.

採取した試料液中のピラゾレートは次のようにして定 量した. 試料液に飽和食塩水 $10 \mathrm{ml}$ を加え, 分液ロート を用いてェチルェーテル $50 \mathrm{ml}$ で 2 回抽出した。溶媒を 留去し, 厚さ $0.5 \mathrm{~mm}$ のシリカゲルプレート $\left(\mathrm{HF}_{254}\right.$, メ ルク社）を用い, ベンゼン：エタノール 9:1 で展開し てピラゾレートを分離し，その部分をかきとりエタノー ル $50 \mathrm{ml}$ で抽出したのち，258 $\mathrm{nm}$ における吸光度を測 定し, 別に求めた検量線よりピラゾレートの量を算出し た.

この值からピラゾレートの粒度分布を求め, そのうち $1.2 ， 2.5,5 \mu \mathrm{m}$ におけるふるい上積算分率を RosinRammler 線図 ${ }^{28)}$ 上にプロットし，作図法により $36.8 \%$ 径 $\left(D_{36.8}\right)$, および比表面積 $\left(S_{w}\right)$ を求めた。

\section{3. 除草効果試験}

1）ワグネルポット試験

面積 $200 \mathrm{~cm}^{2}$ のポットに滋賀県野洲町の水田土壌 (Table 3) を詰め, 化成肥料（千代田化成肥料® 14-814）を $200 \mathrm{~kg} / \mathrm{ha}$ の割合で加光, 加水して全層に混和し, 代かきした. それぞれ別のポットに，タイヌビエ (Echinochloa oryzicola) は種子 $1 \mathrm{~g}$ 它土壌表層 $0.5 \mathrm{~cm}$ に混和播種し,ミズガヤツリ(Cyperus serotinus) は塊茎 2 個を土塞表面に置き, ウリカワ (Sagittaria pygmaea) は塊菱 2 個を深さ $1 \mathrm{~cm}$ に植えつけ, 水深を $4 \mathrm{~cm}$ とし た. 2 日後 (発芽前) および 9 日後 (タイヌビエ 1 葉期)
Table 3 Physical properties of soils used in pot tests.

\begin{tabular}{|c|c|c|}
\hline Source & $\begin{array}{l}\text { Yasu- } \\
\text { cho, } \\
\text { Shiga }\end{array}$ & $\begin{array}{c}\text { Moriyama- } \\
\text { shi, } \\
\text { Shiga }\end{array}$ \\
\hline $\mathrm{pH}\left(\mathrm{H}_{2} \mathrm{O}\right)^{\mathrm{a})}$ & 5.80 & 5.52 \\
\hline $\left.\mathrm{CEC}(\mathrm{me} / 100 \mathrm{~g})^{\mathrm{b}}\right)$ & 7.49 & 6.91 \\
\hline Humus $(\%)^{c)}$ & 2.15 & 1.68 \\
\hline Coarse sand $\left.(\%)^{d}\right)$ & 15.3 & 21.4 \\
\hline Fine sand $\left.(\%)^{d}\right)$ & 33.9 & 44.5 \\
\hline Silt $(\%)^{d)}$ & 37.3 & 22.6 \\
\hline $\operatorname{Clay}(\%)^{d)}$ & 13.5 & 11.5 \\
\hline Soil texture ${ }^{e}$ ) & Loam & Sandy loam \\
\hline
\end{tabular}

a) Glass electrode method.

b) AOAC method.

c) Tyurin's method.

d) Pipette method by G. W. Robinson.

e) Classification by the International Society of Soil Science.

に 1.1）項の分級懸濁液をピラゾレートとして $0.5,1$ ， $2,4 \mathrm{~kg} / \mathrm{ha}$ (有効成分量, 以下 a. i. と略記する) の割合 で各ポットに処理した.処理は各薬量を $10 \mathrm{ml}$ に希釈し, コマゴメピペットでかん注した. 代かき後 32 日目に残 草の地上部生体重を測定した。試験は $23 \sim 34^{\circ} \mathrm{C}$ の温室 内で, 漏水や流亡のない条件下， 3 連反復で行ない，水 管理は蒸発による減量を毎朝補給し, 水深 $4 \mathrm{~cm}$ を維持 した.

2）コンクリートポット試験

$1 \times 1 \mathrm{~m}$ の屋外コンクリートポットに滋賀県守山市の 水田土壌 (Table 3) を詰め, 前項の化成肥料を $400 \mathrm{~kg} / \mathrm{ha}$ の割合で加え, 加水して深さ $15 \mathrm{~cm}$ に混和し, 代かきし た.タイヌビエ, ホタルイ (Scirpus juncoides) は種子各 5 および $2 \mathrm{~g}$ を，ミズガヤツリは塊茥 5 個を, ウリカワ は塊茎 10 個をそれぞれ 3.1) 項と同様には種または植 えつけた。水稲は日本晴れ 2.5 葉苗を 1 株 2 本仕立てで 16 株移植し, 水深を $5 \mathrm{~cm}$ とした. 3 日後に各粒剤を a.i. 1.5 および $3 \mathrm{~kg} / \mathrm{ha}$ の割合で手まきした。 処理後 3 日 間はポット底部の穴から 1 日当り $2 \mathrm{~cm}$ の割合で漏水さ せ，その後は漏水を中止した。減水後のポットには，毎 朝処理表層を乱さないよう静かに補水し, 水深を $5 \mathrm{~cm}$ と した. 処理 44 日目に雑草を抜きとり, 地上部生体重を 測定した。試験は昭和 53 年 4 月 21 日（田植え）から 6 月 7 日（抜きとり調查）まで各 2 連反復で行なった.

3）ほ場試験

滋賀県中主町の水田（沖積塞土, 減水深 $0.5 \mathrm{~cm} /$ 日 以 
下）で昭和 53 年に実施した. 耕種概要は以下のとおりで あった。荒代かき，4月 29 日;植元代かき，5月 3 日;田 植光, 5 月 6 日 (稚苗機械移植).

水田は 1 区面積 4.06 a に区切り, 田植元 3 日目に粒剂 を a. i. $3 \mathrm{~kg} / \mathrm{ha}$ の割合で手まきした. 水田は通常の栽培 条件で管理し，処理 44 日目に各試験区に $1 \times 1 \mathrm{~m}$ の調査 区を 5 か所設け，区内の残草を抜き取り，草種ごとに地 上部生体重を測定した。

\section{実 験 結 果}

\section{1. 分級されたピラゾレートの除草効果}

1）分級懸濁夜中のピラゾレートの粒度

実験方法 1.1）項で分級したピラゾレートの粒度分布 をFig. 1 に示した. 粒度画分Eはやや幅の広い粒度分布 となり，実際の粒度は 30 50 $\mu \mathrm{m}$ であった. 他の分級䀣 濁液はいずれも目標とした粒度画分に分級されていた。

2) 除草効果

これらの分級眯濁液を用いポ゚ット試験によりピラゾ レートの粒度が除草効果に及ぼす影響を調べた。

ウリカワ，ミズガヤッリ植えつけ 2 日後（発芽前）お よび 9 日後 (2 葉期) 処理, ならびにタイヌビエ播種 2 日後（発芽前）処理に打ける各粒度画分の除草効果を Fig. 2 に示した.

ピラゾレートにもっとも感受性の高いウリカワに対し ては, a. i. $0.5 \mathrm{~kg} / \mathrm{ha}$ の薬量で，もっとも粗い粒度画分 $\mathrm{E}(37 \sim 44 \mu \mathrm{m})$ でも，ほぼ完全な除草効果を示したが， タイヌビェでは, $20 \mu \mathrm{m}$ より粗い画分で除草効果が低下 し，ミズガヤッリでは a. i. $1 \mathrm{~kg} / \mathrm{ha}$ の薬量でも，10 $\mathrm{m}$ より粗い画分では除草効果が低下した。ミミ゙ガヤッリで は, a. i. $0.5 \mathrm{~kg} / \mathrm{ha}$ の薬量では各画分とも除草効果は劣 り，粒度画分間に差はみられなかった。薬剤処理時期と の関係では，とくにミズガヤツリの発芽後処理で粗い画 分の効果不足が顕著であった。タイヌビエに対する発芽 後処理の効果は a. i. $0.5 \mathrm{~kg} / \mathrm{ha}$ の薬量ではどの画分も低 く，粒度間の差はみられなかった。

以上のように，ピラゾレートの除草効果は草種によっ ては主剤の粒度の影響を受け，ピラゾレートに抵抗性の 草種ほどピラゾレートを微細にする必要があった。

\section{2. 粒剤に製剤した場合の主剤粒度と除草効果}

1）ピラゾレート粉砕品の粒度

実験方法 1.2) (1)項の粉砝品のビラゾレート粒度を Fig. 3 に示した. 乾式粉砕品は粉砕回数とともに粉䂶が 進行したが，IVでは大型機特有のいわゆる“とび”によ る粗粒子が残存し，その量はIIIより多かった。湿式粉砕 品 $\mathrm{V}, \mathrm{VI}$ では, $1.2 \mu \mathrm{m}$ 以下の微細部分が増加した. こ

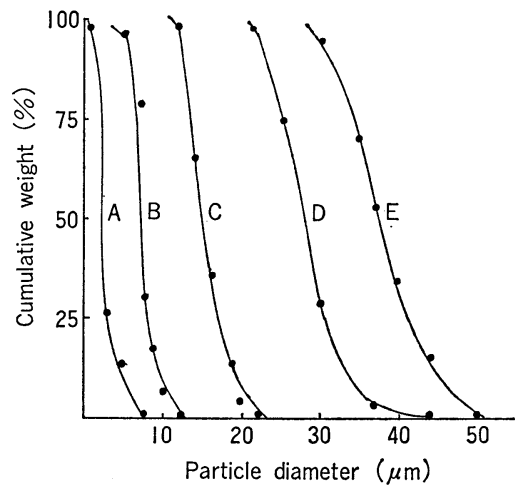

Fig. 1 Particle size distributions of pyrazolate in classified suspensions.

A: $0-5 \mu \mathrm{m}, \quad$ B: $5-10 \mu \mathrm{m}, \quad$ C: $10-20 \mu \mathrm{m}, \quad \mathrm{D}$ : 20-37 $\mu \mathrm{m}, \mathrm{E}: 37-44 \mu \mathrm{m}$.
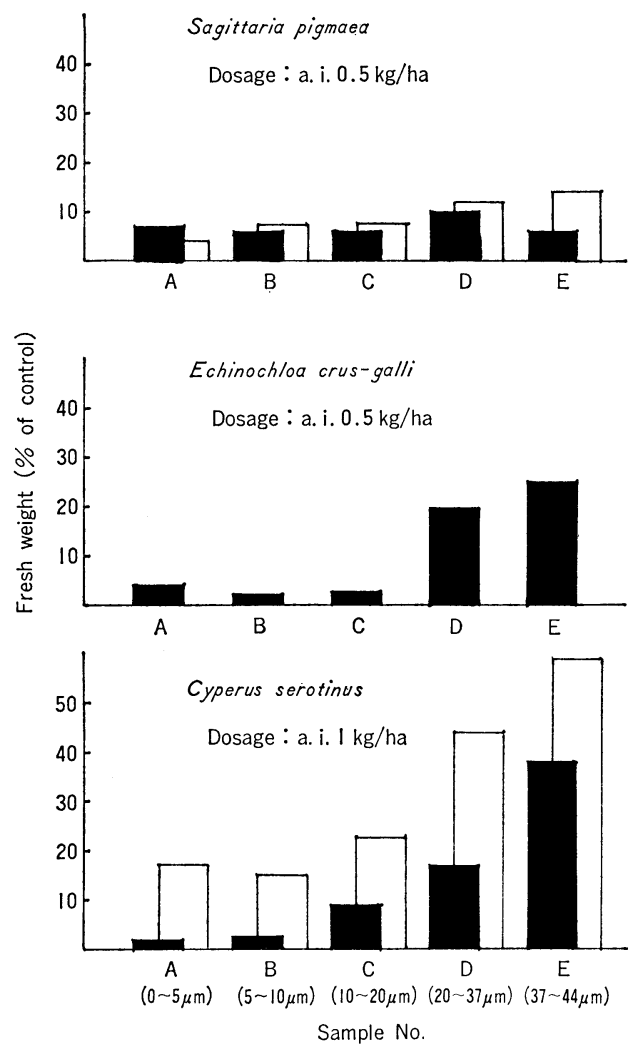

Fig. 2 Relationship between particle size of pyrazolate and the herbicidal efficacy against Sagittaria pygmaea, Echinochloa oryzicola, and Cyperus serotinus.

Postemergence application,

Preemergence application. 


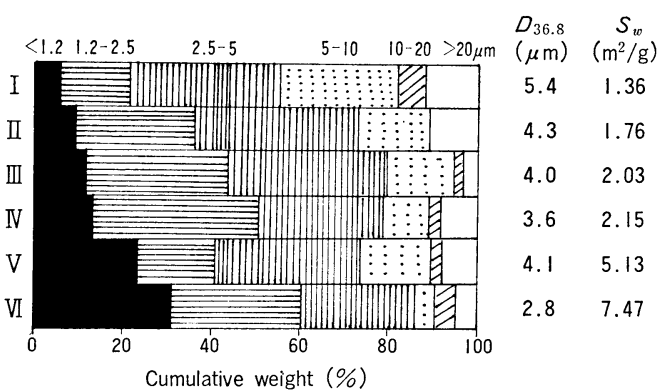

Fig. 3 Particle sizes of pyrazolate used in the herbicidal tests.

I: Pulverized once with Jet-Mill@, II: Pulverized twice with Jet-Mill@, III: Pulverized three times with Jet-Mill@, IV: Pulverized four times with Jet-O-Mizer®, V: Pulverized for $1 \mathrm{hr}$ with Attritor®, VI: Pulverized for $2 \mathrm{hr}$ with Attritor $\bigotimes_{\text {. }}$

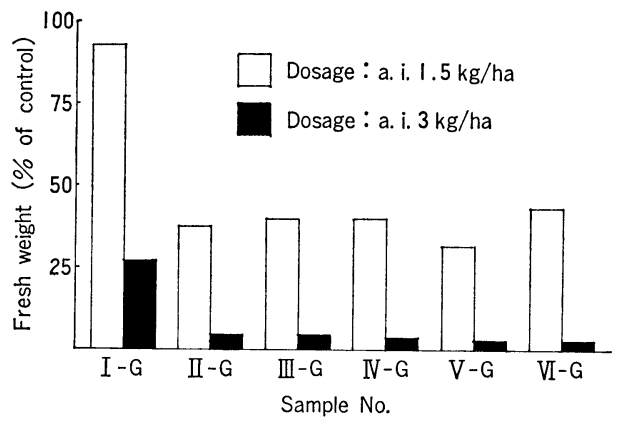

Fig. 4 Herbicidal efficacy of pyrazolate granules in outdoor pots.

I-G, II-G, III-G, IV-G, V-G, VI-G: Granules containing pyrazolate particles I, II, III, IV, V, and VI, respectively (See Fig. 3 and Table 2).

のため, Vの $S_{w}$ はIVの約 2.5 倍となった. VIは $1.2 \mu \mathrm{m}$ 以下の微細部分が $30 \%$ に達し， $D_{36.8}$ および $S_{w}$ からみ ても 6 サンプル中で最も細かかった.

2) 除草効果

(1) コンクリートポット試験

屋外コンクリートポットにおける除草効果試験の結果 を Fig. 4 に示した. I-G $\left(S_{w} 1.36 \mathrm{~m}^{2} / \mathrm{g}\right)$ の除草効果は明 らかに劣った。他のサンプル間に差はみられなかった。 残草の多くはピラゾレートがやや効きにくいホタルイ で，他の草種では差は認められなかった。

(2) ほ場試験

ほ場試験の結果を Fig. 5 に示した。除草効果は, III-G, および $\mathrm{IV}-\mathrm{G}\left(S_{w}\right.$ 各 $\left.2.03,2.15 \mathrm{~m}^{2} / \mathrm{g}\right)$ がもっとも高く, 次いでV-G, VI-G $\left(S_{w}\right.$ 各 $\left.5.13,7.47 \mathrm{~m}^{2} / \mathrm{g}\right)$ で, I -G およ

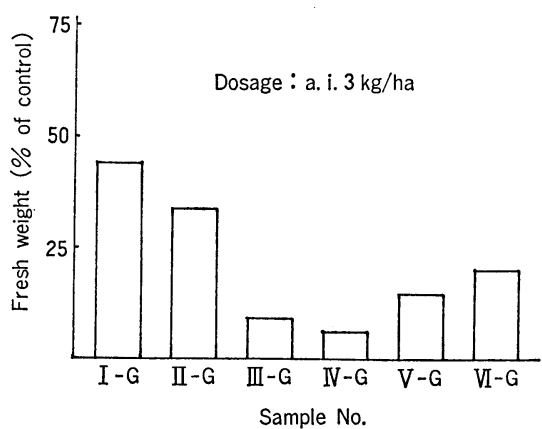

Fig. 5 Herbicidal efficacy of pyrazolate granules in a paddy field.

I-G, II-G, III-G, IV-G, V-G, VI-G： see Fig. 4.

びII-G $\left(S_{w}\right.$ 各 $\left.1.36,1.76 \mathrm{~m}^{2} / \mathrm{g}\right)$ は明らかに劣った.

このように，ほ場に沶いて粒㓣を処理して高い除草効 果を得るために必要なピラゾレートの粒度は $S_{w}$ 約 $2 \mathrm{~m}^{2} /$ gで，粒度が粗くても細かすぎても除草効果は低下した。

\section{考察}

水田に処理されたピラン゙レートは, 徐々に田面水に溶 解拡散したのち, 順次活性成分 DTP に加水分解され, 生成した DTP は流亡, 溶脱, 光分解 ${ }^{29)}$, 微生物分解 ${ }^{30)}$, 植物による吸収を経ながら，田面水中濃度と平衡関係を 保ちつつ, 土䁃表面に吸着 ${ }^{31)}$ されて DTP の处理層を形 成し，除草効果を発現すると考光られている．この場合， 主羭の粒度が細かいほどピラゾレートの溶出，すなわち DTP の生成は早いが,一方で上記のような過程による消 失も生じやすい. DTP の供給と消失のバランスから除 草効果をもっとも強く発現する溶出パターンがあり，こ れに近い溶出を示す製郕が除草効果も高いと考えられ る. DTP の生成が遅い場合は雑草の生育に追いつけず, 逆に，早すぎる場合は消失が早く，真に必要なときに水 田中の DTP が必要量存在しなくなる.

ピラゾレートの分級懸濁液を用いたポット試験，およ び粒度の異なるピラゾレートを含有する粒剂を用いたコ ンクリートポット試験の結果，ピラゾレートの粒度が粗 くなると，抵抗性の草種ほど除草効果が低下した. 一方， 同じ粒剂を用いたほ場試験では，ピラゾレートの粒度が 粗い場合だけでなく，細かすぎる場合にも除草効果は低 下した．この理由は次のように考えることができる．

コンクリートポット試験では，処理直後の 3 日間，底 部の穴から漏水させたが，横移動による田面水の流出は なかった．DTPは下方移行性は小さいことが知られて おり ${ }^{33)}$ ，ピラゾレートの粒度が細かく DTP の生成が早 
い粒郕でも，DTP の溶脱は少なく，高い除草効果を示 したと考えられる。一方，ほ場試験はコンクリートポッ 卜試験に比して, 試験期日が 8 日間遅く，その分だけ水 温は高かったと推定される.ピラゾレートの溶出や DTP への加水分解は温度依存性が高いから，ピラゾレートの 粒度が細かい粒剤は田面水中での DTP の生成が早かっ たと考元られる．また，一般に，田植元直後の水田は土 䁃の状態が不安定で，畔からの漏水など横移動による 田面水の流出が多い：ピラゾレートの粒度が細かい粒刘 は処理後早い時期に生成した DTP が，田面水の流出と ともに流亡したため除草効果が低かったと推定される. どちらの試験でも，ピラゾレートの粒度が粗い粒剂は， DTP の生成が遅いため雑草の生育に追いつけず,除草効 果が不十分であったと考党られる。このように，必要な ときに水田中に DTP が十分量存在しないような条件で は，1.2) や 2.1) (1)に示されるようにピラゾレートに対 し抵抗性の草種から除草効果が低下寸るものと考兄られ る.

前述したように, 水に難溶性の固体農薬の粒度と効力 については多くの報告があり，有効成分が微細なほど効 力が高いものと，最適粒度があるものとに大別できる. しかし，水田用除草剂では最適粒度があるという報告は みられない.ピラゾレート粒戍は，ほ場では $S_{w}$ 約 $2 \mathrm{~m}^{2} /$ g のものがもっとも高い除草効果を示したが，この原因 は, (1)ピラゾレートがきわめて難溶性のため, 粒度が粗 い場合はピラゾレートの溶出が遅く，除草効果に十分な 量の DTP が生成しない, (2)ピラゾレートより加水分解 されて生成する活性成分 DTP は水に対する溶解度が比 較的高いため, ピラゾレートの粒度が細かすぎると田面 水中への DTP の生成が早く, 田面水の流出がある条件 では DTP が流亡するためと考えられる.

\section{要 約}

水田除草剤ピラゾレートの粒度と除草効果の関係を検 討した. ピラゾレートを粒径 $44 \mu \mathrm{m}$ 以下で 5 画分に分 級し, 懸濁液で除草活性を評価すると, 発芽前処理では, ウリカワには a. i. $0.5 \mathrm{~kg} / \mathrm{ha}$ の薬量でどの画分もほぼ 完全な除草効果を示したが，タイスビエには $20 \mu \mathrm{m}$ より 粗い画分は活性が低下し，ミズガヤッリではa. i. $1 \mathrm{~kg} / \mathrm{ha}$ の薬量でも $10 \mu \mathrm{m}$ より粗い画分は活性が劣った. 発芽後 処理では, 粗い画分の活性が低い傾向がより顕著であっ た.また，粒度の異なるピラゾレートの粉砕品を用い， 押し出し造粒法によりつくられた粒剂の除草活性を評価 すると，ポット試験では粒度の粗いピラゾレートを含有 する粒郕 $\left(S_{w} 1.36 \mathrm{~m}^{2} / \mathrm{g}\right)$ は劣った。ほ場でも有効成分
が粗い粒剂 $\left(S_{w} 1.36,1.76 \mathrm{~m}^{2} / \mathrm{g}\right)$ は活性が劣ったが， 有効成分がきわめて微細な粒剤 $\left(S_{w} 5.13,7.47 \mathrm{~m}^{2} / \mathrm{g}\right)$ も 活性が低下する傾向があり， $S_{w}$ 約 $2 \mathrm{~m}^{2} / \mathrm{g}$ のピラン゙レー 卜を含有する粒剤がもっとも活性が高かった。

終りに，本研究に当たりご助言ご指導いただいた当研 究所長 石田三雄博士，実験の一部を担当していただい た新藤正宏，寺村正弘，田井中昌子の各氏に深甚なる謝 意を表します。なお，Table 3 は東京農業大学土壌学教 室の測定值である.

\section{引用 文 献}

1）石田三雄 - 松井孝司 - 矢内利明 $\cdot$ 川久保克彦 - 本 間豊邦・谷沢欽次 - 中川昌之・奥平洋己：三共研 年報 36, 44 (1984)

2) J. M. Hamilton, D. H. Palmiter \& G. L. Mack: Phytopathology 33, 533 (1943)

3) E. F. Feichtmeier: Phytopathology 39, 605 (1949)

4) 高橋清興：農薬の物理化学的研究, 三共(株)農薬 部, p. 59, 1951

5) H. P. Burchfield \& G. L. McNew: Contrib. Boyce Thompson Inst. 16, 131 (1950-1952)

6) G. L. McNew \& H. P. Burchfield: Contrib. Boyce Thompson Inst. 16, 163 (1950-1952)

7）黑坂諫雄・鎌田 裕・奥田逸輝・嘉戸 勝：農薬 生産技術 14，23（1966）

8) P. A. Backman, G. D. Munger \& A. F. Marks: Phytopathology 66, 1242 (1976)

9) W. Mass: “Advance in Pesticide Science," ed. by H. Geissbühler, Part 3, Pergamon Press, Oxford, p. 772,1978

10）坂本 涁：農薬一デザインと開発指針,山本 出, 深見順一編, ソフトサイエンス社, pp. 1033-1034, 1979

11）中村利家・清水宏道・藤本昌彦・高日幸義・近藤 泰彦：農薬誌 6, 293 (1981)

12) R. E. Holm \& A. F. Marks: Hortscience 11, 324 (1976)

13) E. J. Butterfield, R. J. Pocchiari, \& W. R. Landis: Phytopathology 71, 864 (1981)

14) A. B. Hadaway, F. Barlow, \& C. R. Turner: Bull. Entomol. Res. 60, 17 (1970)

15）鎌田 裕・井上忠彦・近藤和信・平尾忠紀：農薬 生産技術 22, 2 (1970)

16）鎌田 裕 - 近藤和信・坂本 彬・井上忠彦：農薬 生産技術 24，27（1971）

17) S. J. Yu \& F. O. Morrison: Can. Entomol. 101, 846 (1969)

18）坂本 涁：植物防疫 28, 363 (1974)

19）藤本昌彦・西田 必 ・ 山本慎二郎・ 中村利家：農 薬誌 6, 301 (1981)

20）大林 久 $\cdot$ 河野義明 $\cdot$ 川上 剛 - 佐藤安夫：武田 研究所報 42, 78 (1983) 
21) A. Sakamoto, K. Nakamura, S. Hayashi \& S. Maeno: Abstr. Fifth Int. Congr. Pestic. Chem., VIII b-5, 1982

22) 近内誠登: 杂隹草研究 12, 7 (1971)

23) A. Rahman: Weed Res. 24, 255 (1984)

24）粉体工学研究会：粒度測定技術, 日刊工業新聞社, p. 165,1975

25）粉体工学研究会：粒度測定技術, 日刊工業新聞社, p. 125,1975

26）粉体工学研究会：粒度測定技術, 日刊工業新聞社, p. 144,1975

27）粉体工学研究会：粒度測定技術, 日刊工業新聞社, p. 146,1975

28）粉体工学研究会：粒度測定技術, 日刊工業新聞社, p. 13,1975

29）山岡 剛・安藤 満 - 辻野泰宏 - 中川昌之：未発 表

30）加藤重博 - 中神和人 - 中西逸朗 - 高日幸義：未発 表

31）山岡 剛・当寺ケ盛学: 未発表

32）山岡 剛- 中川昌之 - 石田三雄: J. Pesticide Sci. 12, 209 (1987)

33）山岡 剛・当寺ケ盛学 - 石田三雄: 未発表

34）谷沢欽次 - 河西史人：三共研年報 37, 121 (1985) 